\title{
10th Session of the General Assembly of the International Federation of Red Cross and Red Crescent Societies
}

(Geneva, 27-30 November 1995)

The 26th International Conference of the Red Cross and Red Crescent was preceded by the 10th Session of the General Assembly of the International Federation of Red Cross and Red Crescent Societies, which was held in Geneva from 27 to 30 November 1995 and attended by almost 600 delegates from 179 countries. That figure included both delegates from member National Societies and observers from emerging Societies.

In his opening address Mr Mario Villarroel Lander, President of the Federation, reviewed the state of the Federation and its activities since the previous session held in Birmingham and expressed his hopes for the future. With special reference to the Strategic Work Plan, he stressed that active and constant support from the National Societies was a matter of crucial importance.

\section{Eight new members of the Federation}

The eight new National Societies recognized by the ICRC since the General Assembly held in Birmingham in 1993 were all admitted to the Federation. They were the Societies of Andorra, Equatorial Guinea, Turkmenistan, Uzbekistan, Armenia, Azerbaijan, Belarus and the Former Yugoslav Republic of Macedonia (Makedonski Crven Krst).

\section{Report of the Secretary General of the Federation}

Mr George Weber gave an overview of the Federation's activities since the previous General Assembly, emphasizing in particular the wide variety of relief operations conducted by the Federation in extremely complex situations around the world, the large number of National So- 
cieties (70 according to official reports) using the Strategic Work Plan as a frame of reference for planning and executing their programmes, and the growing attention being paid to the development aspect in emergency relief operations and to disaster preparedness among National Societies.

Mr Weber went on to outline the Federation's priorities for the coming years, placing emphasis on the need for a firmer commitment to established goals, in particular those intended to enable vulnerable people to avert, cope with and recover from disasters.

\section{Strategic Work Plan}

Referring to Decision No. 35 taken by the General Assembly in Birmingham in 1993 on the updating and execution of the Strategic Work

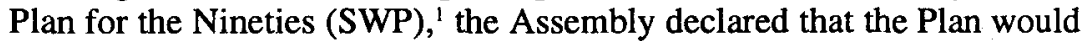
remain in force until the end of the decade. It urged all National Societies to develop or continue to implement their own SWPs, selecting activities outlined in the Federation's Plan and regularly sharing information on their implementation with the Secretary General so as to enable him to report on each and every Society's achievements to the 11 th Session of the General Assembly in 1997; they should also ensure that adequate funds, coming from all national sources and preferably non-earmarked, were made available to the Secretariat for implementation of the Plan.

\section{Report of the Development Commission}

After adopting the Commission's report, the Assembly approved the Red Cross and Red Crescent Development Policy, which focused on the need to strengthen the capacity of vulnerable communities in their daily lives. The Assembly also stressed the urgent need to increase the participation of women in all aspects of Red Cross and Red Crescent action and called for greater support by donor Societies for the Development Fund.

\section{Report of the Health and Community Services Commission}

The Assembly approved the Commission's report deploring the widespread deterioration in the health and welfare of the most needy communities and expressing concern about the discrepancy between resources allocated for emergency relief and those devoted to long-term community

${ }^{1}$ See IRRC, No. 297, November-December 1993, p. 506; and No. 301, July-August 1994 (special issue on "the Red Cross, the Red Crescent and vulnerable communities"). 
development; this imbalance was detrimental to the empowerment of vulnerable groups. In the context of that general decline in health and social service systems, Red Cross and Red Crescent action was becoming particularly important.

The Commission focused its attention on disease prevention and promoting health and social welfare, and recommended that National Societies should become actively involved in the development of programmes relating to the health of women and children, water and sanitation, communicable disease control, psychological support for disaster victims and first aid.

Lastly, the Assembly adopted a decision concerning Red Cross and Red Crescent work with migrants, which called upon National Societies to consider taking action in behalf of migrant populations within the framework of the SWP, which centred on assistance to the most vulnerable, and invited them to encourage migrants to participate in their activities as volunteers or employees, depending on the legal provisions in force in each country.

\section{Report of the Youth Commission}

After hearing the Commission's report, which highlighted the development and implementation of youth policy and strategy in all the National Societies, the Assembly recommended that, in implementing the SWP, National Societies should give due importance to the following priorities concerning Red Cross and Red Crescent youth: the position, recruitment and management of youth volunteers; education and training; networking within the regions; health issues; minorities, the rights of the child and human rights; community action; the links between youth and adult groups within National Societies; and fundraising for youth activities.

Another decision was adopted urging National Societies to make financial contributions to the Fund so that it could rapidly become operational.

\section{Report of the Disaster Relief Commission}

Since the previous General Assembly the Commission had looked at ways of improving disaster relief under five main headings: the changing nature of the United Nations system and its implications for the Federation; the growing needs of refugees and displaced people; problems arising from increasingly frequent technological disasters; the need for hu- 
manitarian assistance organizations to be active in the field of advocacy; and the need to set high professional standards in humanitarian assistance operations.

The Commission stressed the importance of preserving independence and complying with the Fundamental Principles of the Red Cross and Red Crescent when working with United Nations agencies.

After adopting the Commission's report, the Assembly requested the Commission, in cooperation with the Secretary General, to draw up a global disaster relief policy to guide the Federation in its work, and to update the existing policy on the use of food aid and nutrition in emergency situations and incorporate it in the global policy.

\section{Global revenue generation}

The Secretary General of the Federation introduced a document entitled "Policy framework for global revenue generation", a project aimed at maximizing revenue for the benefit of all National Societies and based on the idea of bringing companies together in pairs.

To that end HelpAd Ltd, a company set up by the Federation in London, was bringing together pairs of companies, one offering advertising space on its products and the other buying the space to advertise its own products, with the money going to the Red Cross and Red Crescent.

The proceeds would go 50:50 to Federation operations and National Societies in multinational deals, and 75:25 in favour of National Societies in national deals.

A trade launch had already been held in London and a full launch was planned for early 1996. Moreover, a foundation chaired by Mr George Weber had been set up in Geneva and would receive the proceeds from HelpAd operations, which were exempt from Swiss cantonal and federal taxes.

The Assembly adopted a decision approving the policy framework in principle and calling upon National Societies to support the HelpAd scheme and to conclude the necessary agreements with HelpAd Ltd for implementing it in their own countries when the occasion arose. It also encouraged National Societies to use the policy framework to increase revenue from traditional sources and discover new ones, and to redouble their efforts to collect funds not only for their own programmes but also for strengthening the international network of National Societies. 


\section{Plan and budget for 1996-1997}

The Assembly approved the Financial Reports for 1993 and 1994 and the plan and budget for 1996-1997, amounting to 52,971,000 and $55,734,000$ Swiss francs respectively.

\section{Relations with international organizations}

The Assembly expressed its satisfaction with the status of permanent observer to the United Nations General Assembly, won by the Federation thanks to the coordinated efforts of its entire membership. In endorsing the document entitled "Cooperation with international organizations", which would guide National Societies in their relations with such bodies, the Assembly noted that the activities of the Federation and National Societies in that respect should be governed first and foremost by the Fundamental Principles of the Red Cross and Red Crescent and by international humanitarian law.

In particular, the Assembly drew attention to the objectives which should guide the Federation and National Societies in their relations with international organizations, including the United Nations, its specialized agencies and special funds and programmes, namely:

- to serve the interests of the most vulnerable and to strengthen the role and capacity of the Federation and the National Societies to meet their humanitarian needs;

- to promote human dignity, the Fundamental Principles of the Red Cross and Red Crescent and humanitarian values;

- to protect the integrity and independence of action of the Red Cross and Red Crescent;

- to broaden and develop the capacity of the National Societies and of the Federation as a whole;

- to offer more effective and efficient humanitarian assistance through enhanced cooperation and communication.

Lastly, the Assembly requested the Secretary General to ensure that the Fundamental Principles of the Red Cross and Red Crescent, international humanitarian law and the Federation's opinions and activities were systematically given the highest possible profile within the United Nations system, intergovernmental bodies and other international forums. The Secretary General should also promote greater recognition among the international community for the Federation as a front-rank service pro- 
vider and a credible defender of the most vulnerable, through cooperation and agreement among National Societies, the Secretariat and its delegations.

\section{Amendments to the statutory texts}

The Assembly decided to postpone until the 11th Session of the General Assembly, due to be held in 1997, its consideration of amendments to the Constitution and corresponding articles of the Rules of Procedure.

\section{Date and venue of the 11th Session of the General Assembly}

The Assembly accepted the invitation of the Spanish Red Cross to host its 11 th Session in 1997.

The Review 